\title{
ВИЗУАЛИЗАЦИЯ В ОТЕЧЕСТВЕННЫХ СМИ: КРИТИЧЕСКИЙ АСПЕКТ
}

\author{
Исабекова Адина Сакеновна \\ магистрант кафедры печати и электронных СМИ \\ специальности DATA-журналистика \\ факультета журналистики КазНУ \\ им. аль-Фараби, г. Алматы, Казахстан
}

Аннотация: В статье рассматриваются основные методы визуализации, которые широко применяются при создании материалов сегодня. Автор исследует специфику ведения медиа бизнеса в рамках общего экономического кризиса.

Ключевые слова: визуализация, дизайн, инфографика, информационная графика, визуальное восприятие.

\section{VISUALIZATION IN DOMESTIC MEDIA: A CRITICAL ASPECT}

\section{Issabekova Adina Sakenovna} master student of the Department of Printing and Electronic Media specialties DATA-journalism faculty of Journalism KazNU named after al-Farabi

\begin{abstract}
The article discusses the main visualization methods that are widely used in the creation of materials today. The author examines the specifics of running a media business in the context of the general economic crisis.

Key words: visualization, design, infographics, information graphics, visual perception.

Площадки, которые на сегодняшний день транслируют крупные потоки информации и размещают контент разного характера, стали деформироваться и подстраиваться под современные тенденции. Одним из ключевых особенностей современной подачи материалов стал их визуальный аспект. Для успешной подачи авторам важно понимать суть психологического фактора поведения человека в данном вопросе.

Целью актуального и идущего в ногу со временем средства массовой информации является сфокусировать читателя на действительно важных цифрах, в некоторых моментах произвести впечатление и оставить в
\end{abstract}


подсознании важные сигнальные факторы. Допустим, донести до потребителя контента среднестатистической газеты «Деловой Казахстан» важность вакцинирования населения для недопущения очередной ударной волны по малому и среднему бизнесу. Не всегда строгий печатный текст сегодня способен преподнести основную мысль в том ракурсе, который аудитория сможет потребить.

Основные методы подачи информации большинства деловой публицистики в традиционных СМИ устарели по нескольким признакам. Вопервых, это связано с психологией поведения человека в отношении потребления контента. Только представьте: вместо традиционной новостной ленты в социальной сети читатель будет тратить от 7 до 10 минут в среднем на прочтение длинного текста, наполненного данными. Современные онлайн платформы многих передовых СМИ позволяют пользователю бегло пробегаться по инфографике и минимальному количеству текста на ней, при этом включая рецепторы фотографической памяти. Это не недостаток, а особенность потребителя сегодня. К которой в перспективе важно приспосабливаться и адаптироваться.

Во-вторых, техническое развитие и улучшение современного программного обеспечения позволяет улучшать качество производимого материала и попросту эволюционирует из года в год. То есть, если 7-10 лет назад дополненная табличным контентом и парой изображений статья считалась мультимедийной и «богатой», сегодня эти инструменты считаются слабой попыткой в создании продукта [1, с.130].

Что актуально сегодня?

Мультимедийность и подвижность любого рода материала. Самым распространенным и эффективным жанром современной журналистики является лонгрид (от англ. 'long read'). Лонгриды не про количество символов и не про продающие формулы текста. Не про то, как правильно подобрать картинки к материалу. И не про количество просмотров, конечно. И даже не про то, как изучить потребности целевой аудитории и попасть текстом в них. Это самый амбициозный, бросающий вызов автору формат контента. Формально любой объемный материал, который хорошо сверстан и наполнен разнообразным содержимым (текст, фото, интерактивный контент), принято считать лонгридом. Да, он длинный - как правило, от 1200 слов или восьми тысяч знаков. Но таким ценным его делает не размер и не навороченная верстка, а определенный подход к работе над материалом. Если снизить количество знаков, он останется 


\section{МЕЖДУНАРОДНЫЙ ИССЛЕДОВАТЕЛЬСКИЙ ФОРУМ

лонгридом. Убрать верстку - он останется лонгридом. Не отразите глубину освоения темы и авторскую подачу - все пропало. Не зря в англоязычной традиции лонгрид еще называется deep read. То есть, истинный смысл - это правильно обосновать определенную точку зрения или рассказать конкретную историю в правильной форме. Плюсом является то, что сам жанр аудиторией дочитывается до конца, если с основными положениями автор справился на «ура». С точки зрения визуализации существует ряд эффективных инструментов и площадок размещения с подходящими положениями. Самый простой и доступный пример эффективности - представьте два одинаковых линейных графика. Один из них статичный, а второй, справа, вырисовывается на ваших глазах и динамика роста или падения показывается направлением линии. Естественно, данная простейшая манипуляция делает акцент на том, что же происходит. И у читателя не будет сомнений по поводу того, что нам демонстрируют оси координат. На том же примере можно продемонстрировать столбчатые диаграммы: если создать анимацию по заполнению той или иной колонки и сопроводить это звуком накопления (например, то, как наливается в пустой бокал вода). На психологическом уровне восприятия читатель точно заполнится, как много (или мало) было заполнено в ту или иную «пробирку» $[2,321]$.

Актуальным сегодня является и видеографика и видео материалы любого характера. Площадки типа YouTube, AiTube (казахстанский аналог), Vevo, Vimeo и др. перевернули научные сферы и доказали эффективность подготовки онлайн презентаций. Школьники и студенты сегодня привыкли пользоваться не только стандартной поисковой системой Google, но и ищут альтернативные методы обучения, так как визуальное восприятие находится на совершенно другом уровне и включает иные функции человеческого мозга. При этом контент может быть абсолютно разным: от формата традиционного репортажа и интервью до 3D-моделирования (отлично подходит в медицине) [3, с. 23]. Все достижения науки, доказанные и совершенные естествоиспытателями, были открыты путем визуального рассмотрения тех или иных ситуаций. Например, Исаак Ньютон и Закон Всемирного Тяготения. Он представил в пространстве модель, где он сидит под яблоней и при действии определенных сил с нее падает плод. Любые технические задачи решаются посредством создания чертежей и воспроизведения ситуации. Поэтому визуализация - один из самых мощных инструментов в работе с оттачиванием восприятия информации [4, с. 48]. 


\section{МЕЖДУНАРОДНЫЙ ИССЛЕДОВАТЕЛЬСКИЙ ФОРУМ

При создании любого типа визуального контента важно помнить о сочетании цветов не только в эстетичном, но и в психологическом факторе человеческого восприятия. Нервные импульсы, посылаемые мозгу при виде определенных оттенков способны создать неверные ассоциации и привести к неправильной передаче сути проблемы. Даже расположение геометрических фигур на графических данных способны повлиять на общее представление и даже создать диссонанс в голове среднестатистического потребителя.

\section{Заключение}

Словосочетание «мировой экономический кризис» - это скорее стандартное описание нашей обыденности, и непростым кризис будет лишь для тех, кто не успел адаптироваться на рынке и применить новую стратегию для функционирования своей деятельности. В отечественной журналистике большие перемены негативно отразились на традиционной печати, телевидении и радио, но те же газеты, журналы и каналы Запада по понятной причине успели среагировать на изменения и превратиться в визуальных журналистов и сделали профессиональный скачок. В мультимедийном кризисе побеждает тот, кто использовал изменения в свою пользу и реализовал себя в этой сфере.

Среди основных критических аспектов в становлении отечественной мультимедийной визуальной журналистике - нехватка профессиональных кадров и незаинтересованность привыкших к уставам прошлых лет журналистов. Современный специалист должен уметь совмещать в себе навыки как в написании текстового материала, так и в создании фото, видео и сопутствующей инфографики. На фоне нехватки «универсалов» возникает также проблема отсутствия правильно выстроенной коммуникации между отделами - дизайнерами-верстальщиками и контент мейкерами. Зачастую текстовое наполнение формируется отдельно от визуального, и неудачный опыт такой модели доказывает ее неэффективность.

При правильно выстроенной стратегии ведения СМИ должна быть выстроена четкая взаимосвязь и взаимозаменяемость специалистов, которые четко понимают ремесло друг друга и знают наверняка, как преподнести авторскую мысль правильно. На фоне отсутствия конкурентов основную долю рынка необъективно занимают медиа гиганты (например, TengriNews) и незаинтересованные в прогрессии СМИ вынуждены пользоваться созданными гигантами материалами. 


\section{МЕЖДУНАРОДНЫЙ ИССЛЕДОВАТЕЛЬСКИЙ ФОРУМ

\section{Список литературы}

1. Желязны Д. Говори на языке диаграмм. М.: Манн, Иванов, Фербер, 2011

2. Stovall J.G. Infographics: A Journalist's Guide. USA: University of Alabama, 1997

3. Анисимова Е.Е. Лингвистика текста и межкультурная коммуникация (на материале креолизованных текстов). М.: Академия, 2008

4. Neurath O. International Picture Language; The First Rules of Isotype. London: K. Paul, Trench, Trubner \& Co., 1936 